\title{
UKRAIŃSKA PRASA KOBIECA W GALICJI WSCHODNIEJ W LATACH 1884-1939
}

\author{
JULIA KUPIDURA \\ Uniwersytet imienia Marii Curie-Skłodowskiej w Lublinie, Lublin — Polska \\ УКРАЇНСЬКА ЖІНОЧА ПРЕСА \\ У СХІДНІЙ ГАЛИЧИНІ В 1884-1939 РОКАХ
}

\begin{abstract}
ЮЛІЯ КУПІДУРА
Люблінський університет імені Марії Кюрі-Склодовської, Люблін - Польща

АНОТАЦІЯ. У статті проаналізовано розвиток жіночої преси в Східній Галичині в 1884-1939 роках. Досліджено жіночі видання, що друкувалися в згаданий час, а також репрезентовано постаті найвидатніших жінок-редакторів.
\end{abstract}

\author{
UKRAINIAN WOMEN'S PRESS \\ IN EASTERN HALYCHYNA IN 1884-1939
}

\section{JULIA KUPIDURA \\ Lublin Maria Curie-Skłodowska University, Lublin — Poland}

ABSRACT. The article focuses on the analysis of the female press in Eastern Halychyna in 1884-1939. The female periodicals, published at that time have been discussed; also prominent female publishers have been represented.

$\mathrm{M}$ arta Bohaczewska-Chomiak swoją pracę poświęconą historii kobiet na Ukrainie nazwała Białym po białym. Kobiety $w$ życiu społeczno-politycznym Ukrainy $w$ latach 1884-19391. Wybór tytułu wytłumaczyła chęcią porównania roli kobiety w ukraińskiej historii do haftu na charakterystycznej ukraińskiej wyszywance, którego na pozór nie widać, jednak, kiedy się przyjrzeć, okazuje się, że nie dość, że się na niej znajduje, to stanowi jej główny i dostojny motyw. Obecnie gender studies oraz studia kobiece na Ukrainie święcą triumfy. Wiele pozycji, poświęconych znamienitym prababkom walczącym o prawa kobiet i niepodległość kraju, pozwalają stwierdzić, że ich rola w historii nie jest już szyta biłym po biłomu, a zaznacza się o wiele wyraźniej. Tym samym kobiety włączane są do ukraińskiej historiografii.

Fenomen rozwoju ruchu kobiecego w Galicji był i nadal jest badany i opisywany przez historyków i kulturoznawców. Konsekwencja i pracowitość sprawiły, że ukraińskie działaczki feministyczne w dwudziestoleciu międzywojennym zapraszane były niemal na wszystkie zjazdy, kongresy i konferencje międzynarodowe. Oznaczało to, że ich głos liczył się nie tylko w Europie, ale również w Stanach Zjednoczonych (Ukrainki w dwudziestoleciu międzywojennym należały do Międzynarodowej Rady Kobiet [International Council of Women], Międzynarodowego Związku Kobiet [International Women Suffrage Alliance] czy Międzynarodowej Ligii Kobiet na Rzecz Pokoju i Wolności [League of Women for Peace and Freedom].

${ }^{1}$ М. Богачевська-Хом'як, Білим по білому. Жінки в громадському житті Украӥни 18841939. Canadian Institute of Ukrainian Studies, University of Alberta, Edmonton 1988. 
Wielość tytułów prasowych Galicji Wschodniej adresowanych do kobiet to kolejny dowód na ich zaangażowanie w ukraińskie życie społeczne i polityczne.

Zakres chronologiczny omawianego tematu to lata od 1884-1939. Cezurę początkową wyznacza założenie przez Natalię Kobryńską w Stanisławowie pierwszej organizacji kobiecej o charakterze feministycznym² ${ }^{2}$ Towarzystwo Kobiet Ruskich [Tовариство руських жінок] i wydanie almanachu „Перший вінок”. Końcową granicę stanowi natomiast wybuch II wojny światowej, wraz z którą zaprzestano drukowania prasy kobiecej. Zakres terytorialny to ziemie wchodzące w skład Galicji Wschodniej. Przez Galicję Wschodnią autorka rozumie termin używany po 1850 roku dla określenia wschodnich terenów Królestwa Galicji i Lodomerii ze Lwowem jak ośrodkiem centralnym, a także Stanisławowem, Tarnopolem, Przemyślem, Sanokiem i Krosnem.

W latach 1884 do 1939 wydawano 12 tytułów prasowych dla kobiet. Niektóre $\mathrm{z}$ nich były almanachami, jednorazowymi wydaniami, inne miały charakter poradników, kolejne ukazywały się regularnie przez dłuższy okres, a ich druk przerwał wybuch drugiej wojny światowej. Gazety te miały różny charakter, założenia i priorytety. Miały trafiać do różnych typów kobiet: mieszkających na wsi, w mieście, artystek, socjalistek, kobiet czynnych zawodowo, matek, kobiet zaangażowanych politycznie, bądź tych, które nie miały ukształtowanej świadomości politycznej, do feministek i tradycjonalistek. Łączył je jeden cel. Miały pielęgnować pamięć o kulturze i języku narodowym, zagrożonych w trudnym dla Ukrainy momencie.

Pojawienie się pierwszego ukraińskiego wydawnictwa dla kobiet związane jest z nazwiskiem Natalii Kobryńskiej, która była także pierwszą ukraińską teoretyczką myśli feministycznej. Idee feminizmu łączyła z socjalizmem. Od najmłodszych lat o jej wykształcenie dbał ojciec Iwan Ozarkewycz. Ponieważ w tym okresie oświata na poziomie gimnazjalnym była niedostępna dla dziewcząt, młoda Natalia czytała literaturę, jaką przynosili do domu jej bracia, uczniowie niemieckiego i ukraińskiego gimnazjum. W 1871 roku wyszła za mąż za Teofila Kobryńskiego. Przy jego boku pogłębiała edukację i zapoznała się m.in. z pracami Jasepha Ernesta Renana, Ferdynanda Larysa, Karola Marksa i Fryderyka Engelsa. Wspólnie przetłumaczyli też dzieło J.S. Milla Poddaństwo kobiet (The Subjection of Women, 1869) jedna z najważniejszych krytyk nierówności płci³

Jak pisze w swojej autobiografii, wszystkie te teksty zachwiały fundamentami jej wychowania: Pamiętam, że bardzo przeżywałam ten czas, kiedy zaczęłam zaznajamiać się z pracami pozytywistów. Prace tej szkoły zaczęły rujnować nie tylko moje religijne wyobrażenia, ale również poglady na życie i porzadek społeczny, który mnie

${ }^{2}$ Autorka świadomie używa w referacie słowa feminizm, który uważa za odpowiedni do danego tematu i zakresu chronologicznego. Bardzo często termin ten postrzegany jest pejoratywnie. Jest to efektem rozumienia całości tego złożonego zagadnienia jako ruch radykalny należący do tradycji dyferencjalistycznej nazywanej często feminizmem postmodernistycznym bądź feminizmem różnicy. Wywodzi się z niej współczesna esencjalistyczna myśl feministyczna, konstruująca alternatywną wizję żeńskiej kultury. Autorki spod znaku ecriture feminine (m.in. Julia Kristeva, Lucy Irigaray, Helene Cixous) poszukują w swych tekstach nowego kobiecego języka, zdolnego wyrazić wyparte przez męską kulturę doświadczenie ciała. Feminizm ten podejmując problematykę ciała, seksualności i obyczaju, nie poprzestawał (jak feminizm liberalny) na wprowadzeniu zmian zmierzających do równouprawnienia kobiety w istniejących strukturach, ale dążył do przewartościowania całości systemu kultury, definiowanego jako patriarchalny i opresyjny wobec kobiet. Autorka nie uważa także za właściwe używanie słowa sufrażystka w odniesieniu do ukraińskich działaczek kobiecych w danym okresie chronologicznym. Ten wąski termin odnosi się jedynie do kwestii uzyskania praw wyborczych (łac. suffragium = głos wyborczy) i dotyczy przede wszystkim ruchu kobiet, jaki powstał w Wielkiej Brytanii i Stanach Zjednoczonych przed pierwszą wojną światową. Ruch sufrażystek związany był głownie z pierwszą falą feminizmu, która kończy się wraz z realizacją jego postulatów.

${ }^{3}$ М. Богачевська-Хом'як, Зазнач. праця, с. 113. 
otaczat. To nie było łatwe. Czułam, że trace pod soba grunt, a silny wewnętrzny konflikt w najwyższym stopniu drażnit moje nerwy ${ }^{4}$.

We wrześniu 1882 roku zmarł Teofil Kobryński. Natalia wyjechała do Wiednia. Tam napisała swoje pierwsze opowiadania, które przyniosły jej sukces i poparcie Ostapa Terleckiego, Mychajła Pawłyka oraz całego młodego pokolenia galicyjskich socjalistów ${ }^{5}$. Jednak głównym celem Kobryńskiej było utworzenie organizacji kobiecej o świeckim charakterze. Udało się to w sierpniu 1884 roku w Stanisławowie. 8 grudnia odbyło się zgromadzenie założycielskie Towarzystwa Kobiet Ruskich, w którym udział wzięło prawie sto kobiet z całej Galicji ${ }^{6}$. Niemal równocześnie powstała idea wydania almanachu. Kobryńska postawiła przed nim trzy główne zadania: zapoznawać kobiety z ideami feminizmu, wzmacniać ich zaufanie do organizacji oraz budować solidarność pomiędzy Ukrainkami po obydwu stronach granicy rosyjsko-habsburskiej ${ }^{7}$. Materiały do almanachu nadsyłane były z wszystkich ziem ukraińskich. W wydanie duży wkład wniosła Ołena Pcziłka, która nie tylko je sfinansowała, ale również zaproponowała nazwę „Перший вінок”. Wielość nadesłanych materiałów skłoniła redakcję do rozpoczęcia przygotowań kolejnego wydania almanachu, zatytułowanego „Другий вінок", który jednak nie został ostatecznie opublikowany.

Ukraińska społeczność Galicji przyjęła pierwsze wydanie gazety redagowanej i wydanej przez kobiety w sposób ambiwalentny. Z jednej strony gratulowano inicjatywy, z drugiej jednak sama gazeta sprzedawała się powoli. Jeszcze dziesięć lat po wydaniu, na łamach kolejnych pism redagowanych przez Kobryńską ukazywały się ogłoszenia o możliwości zakupu almanachu ${ }^{8}$.

W latach 1893-1896 Natalia Kobryńska była redaktorką trzech numerów nowej gazety „Наша доля”. Wydanie kontynuowało socjalistyczne poglądy głównej redaktorki. W pierwszym numerze opublikowano m.in. projekt utworzenia przedszkoli dla dzieci, artykuł analityczny na temat dalszego rozwoju ruchu kobiecego w Galicji, płomienną przemowę dotyczącą praw kobiet autorstwa bukowińskiej nauczycielki i pisarki Jewhenii Jaroszyńskiej, wezwanie Anny Gramaliuk pt.: Mieszkanki wsi Tyszkiwci powiatu gródeckiego do walki z analfabetyzmem! oraz artykuł o domowym niewolnictwie kobiet. W „Нашій долі” prowadzono także rubrykę o światowym ruchu kobiecym oraz strony literackie ${ }^{9}$.

Ostatecznie działalność Natalii Kobryńskiej spotkała się z niezrozumieniem ze strony kobiet Galicji Wschodniej. Powody takiego stanu rzeczy thumaczy Marta Bohaczewska-Chomiak: Kobryńska nie zrobiła z ukraińskich kobiet świadomych feministek, nie przekonała ich o nadzwyczajnej wadze kobiecej emancypacji, bo odczuwały one bardziej dyskryminację narodowa, aniżeli płciowa. Kobryńska zachęciła jednak kobiety do pracy społecznej oraz skierowała je na droge pragmatycznego feminizmu ${ }^{10}$.

Kolejną inicjatywą wydawniczą była gazeta „Мета” — czasopismo ukraińskich kobiet postępowych. Gazeta wydawana i redagowana była przez Darię Starosolską Szuchewycz, działaczkę społeczną i wykładowczynię Instytutu Muzycznego ${ }^{11}$. Kie-

${ }^{4}$ Cyt. za: М. Богачевська-Хом'як, Зазнач. праия, с. 113. Tłumaczenie własne. Dalej, jeśli nie wskazano inaczej, również.

${ }^{5}$ Tamże, s. 115.

${ }^{6}$ С. Кость, Жіноча преса, [w:] Źródło elektroniczne: http://www.nbuv.gov.ua/portal/natural/ vlnu/Jur/2007_30/Visnyk\%2030_P2_02_Kost.pdf, (31 października 2011).

${ }^{7}$ М. Богачевська-Хом'як, Зазнач. праця, с. 119.

${ }^{8}$ Tamże, ss.119-120.

9 Tamże, s. 126.

10 Tamże, s. 128.

${ }^{11}$ С. Кость, Зазнач. праця. 
rowana była do kobiet wykształconych, zamieszkujących miasta. Głównym jej zadaniem miało być uświadamianie szerokich kręgów kobiecych, wciagnięcie ich w życie społeczne tak, aby kobieta mogła i miała odwage zabierać głos we wszystkich ogólnoludzkich sprawach ${ }^{12}$.

Na łamach „Мети” publikowano eseje poświęcone emancypacji kobiet, recenzje książek oraz biografie działaczek feministycznych z różnych krajów. W 1908 roku na stronach gazety ukazały się pierwsze postulaty zjednoczenia ukraińskich organizacji kobiecych. Efektem tej inicjatywy było powołanie dwóch kongresów kobiet we Lwowie w 1908 i 1909 roku. Były to najważniejsze osiagnięcia gazety, która w sumie wychodziła przez osiem miesięcy.

Kolejną cenną, choć równie krótką inicjatywą wydawniczą kobiet, było „Жіноче діло”, które funkcjonowało jako dodatek do gazety „Діло” w 1912 roku. Jego redakcją zajęła się Ołena Kysiłewska, późniejsza senatorka II RP. Na łamach kwartalnika poruszano tematy związane $\mathrm{z}$ emancypacją kobiet, koniecznością ich edukacji oraz politycznym i ekonomicznym uniezależnieniem się ${ }^{13}$.

Nadciagające widmo wojny powodowało upolitycznienie sprawy kobiecej. Pomimo tego, że kobiety coraz częściej publicznie wypowiadały się na tematy polityczne i były aktywne w różnych sferach życia społecznego, nadal nie były doceniane przez liderów ukraińskich ugrupowań. W grudniu 1912 roku działaczki ruchu kobiecego nie zostały zaproszone przez żadną z trzech największych galicyjskich partii politycznych do rozmów, podczas których decydowano o udziale Ukraińców w wojnie po stronie Austro-Węgier. Kobiety podejmowały jednak własne inicjatywy. We Lwowie organizowano wykłady i dyskusje na temat możliwości ich udziału w nadchodzącej wojnie. Ołena Stepaniw w swoich wspomnieniach $W$ przededniu wielkich wydarzeń. Własne doświadczenia i przemyślenia 1912-1914 ${ }^{14}$ uznaje grudzień 1912 roku za moment przełomowy w przebudzaniu się myśli nacjonalistycznej i wojskowej w środowiskach kobiecych i wśród młodzieży. Zorganizowano wtedy forum organizacji kobiecych, które cieszyło się sporym zainteresowaniem w kręgach lwowskich. Ołena Stepaniw wystąpiła na nim z referatem, postulującym konieczność uczestniczenia kobiet w sferze politycznej, walce na froncie oraz kwestią ich przedstawicielstwa w ukraińskiej Radzie Narodowej.

Tymczasem społeczeństwo Galicji zwracało coraz większą uwagę na rolę kobiety w czasie wojny. Pojawiały się liczne artykuły w prasie lwowskiej na temat uczestnictwa kobiet w wojnach bałkańskich ${ }^{15}$.

Znamiennym jest fakt, że działania polityczne, mające na celu propagowanie sprawy narodowej w społeczeństwie, pozwoliły na posunięcie do przodu spraw związanych z kwestią kobiecą. Działaczki, o których wspomina Ołena Stepaniw, wielokrotnie wysyłały delegacje do władz państwowych. Tak było na przykład w 1912 roku. Przedstawicielki galicyjskich kobiet pojechały do Agenora Gołuchowskiego, posła i marszałka krajowego Galicji w sprawie przyznania kobietom praw wyborczych w nowej ordynacji. Co szczególnie ciekawe, były to delegatury założone z Polek i Ukrainek. Późniejsza współpraca, zwłaszcza w okresie międzywojennym nie układała się tak dobrze. Kobiety poróżnił sprzeczny interes ich narodów ${ }^{16}$.

${ }^{12}$ Н. Олійник, Жіноча преса в Україні: минуле та сучасність, [w:] Źródło elektroniczne: http://www.ji.lviv.ua/n27texts/oliynyk.htm (31 października 2011).

${ }^{13}$ С. Кость, Зазнач. праия.

${ }^{14}$ О. Степанів, На передодні великих подій. Власні переживання і думки 1912-1914, Львів 1930.

15 Tamże, s. 27.

${ }^{16}$ М. Богачевська-Хом’як, Зазнач. прачя. с. 141-143. 
Wraz z wybuchem pierwszej wojny światowej zaprzestano działań wydawniczych. Wiele działaczek ruchu kobiecego udało się na emigrację. W literaturze przedmiotu można spotkać opinie, że ruch kobiecy przestał istnieć. Właściwszym wydaje się jednak stwierdzenie, ze ruch ten zmienił swój charakter. Warunki polityczne i wojenne wymagały bowiem od kobiet nie tylko pomocy socjalnej, sanitarnej czy charytatywnej, ale również oczekiwały od nich walki z bronią w ręku. Bohaterkami walczącymi w oddziałach Strzelców Siczowych i Ukraińskiej Armii Halickiej były: Ołena Stepaniw, Anna Dmytrenko, Sofija Hałeczko i wiele innych. Bohaterstwo, jakim wykazały się kobiety w czasie bitw pierwszej wojny światowej, dało podstawy do dyskusji nad rolą, jaką kobiety pełniły w społeczeństwie. Walka kobiet na froncie była zatem kolejnym krokiem ku emancypacji, postawionym przez nie mniej lub bardziej świadomie.

Po zakończeniu wojny, w lutym 1919 roku Ukrainki założyły gazetę „Наша мета”. Redaktorką naczelną została Daria Starosolska. Będąc pod auspicjami Ukraińskiej Partii Socjaldemokratycznej, gazeta adresowana była do kobiet bez względu na partyjne $i$ socjalne różnice ${ }^{17}$. Propagowanie idei ukraińskiej niepodległości nie było proste w warunkach polskiej cenzury, która konfiskowała poszczególne numery ${ }^{18}$.

W „Нашій меті” opublikowano m.in. interesujący artykuł Mileny Rudnickiej Lwowskie aktywistki podczas listopadowego przewrotu, który stanowił podsumowanie udziału kobiet w działaniach wojennych. Rudnicka krytykowała w nim galicyjskich polityków za to, że nie dopuścili kobiet do udziału w walkach, natomiast same kobiety za zbyt dużą bierność. Na łamach „Нашої мети” poruszano również tematykę feministyczna, głównie dzięki tekstom Rudnickiej i Kisielewskiej. Wiele miejsca poświęcano sprawie patriotycznego wychowania dzieci, oświacie, drukowano teksty literackie. „Наша мета” przestała ukazywać się w 1920 roku.

W 1917 roku powstał Związek Ukrainek [Союз українок]. Od początku działalności miał on ściśle narodowy charakter. W tym duchu wypowiadała się Milena Rudnicka na zjeździe ukraińskich kobiet we Lwowie w 1921 roku. W imieniu zebranych wyraziła pragnienie i gotowość uczestniczenia we wszystkich ważnych dla kraju decyzjach. Podkreśliła również, że kobiety za główny i niezmienny polityczny cel uważają niepodległą Ukrainę ze stolicą w Kijowie ${ }^{19}$.

Pierwszą próbą stworzenia oficjalnego organu wydawniczego było wydanie w 1922 „Жіночого вісника”. Gazeta ta ukazywała się jako dodatek początkowo do gazety „Громадський вісник”, a następnie „Діло”20 .

W 1925 roku wyszło pierwsze wydanie miesięcznika „Нова хата”. Gazeta ta rozpoczęła najlepszy okres w historii zachodnioukraińskiej prasy kobiecej. Początkowo poświęcona była modzie i sprawom gospodarstwa domowego, jednak w latach 1926-1939 miesięcznik wziął na siebie dużo ważniejszą misję. Poruszał przede wszystkim tematy związane ze sztuką narodową. Głównym celem gazety było podtrzymywanie pamięci o sztuce i kulturze narodowej oraz ukazywanie jej w kontekście patriotycznym. Dużo miejsca poświęcono strojowi ludowemu. Zorganizowano na przykład specjalną akcję, mającą na celu zbieranie i ocalenie strojów z różnych regionów Ukrainy Zachodniej ${ }^{21}$.

Niemal równocześnie z wydaniem „Нової хати”, w Kołomyi zaczęto redagować gazetę „Жіноча доля”. Główną inicjatorką i redaktorką była Ołena Kysiłewska.

\footnotetext{
${ }^{17}$ С. Кость, Зазнач. праияя.

${ }^{18}$ Tamże.

19 Tamże.

${ }^{20}$ Н. Олійник, Зазнач. праця.

${ }^{21}$ С. Кость, Зазнач. прачя.
} 
Początkowo gazeta wychodziła co miesiąc, później co dwa tygodnie. Wydawnictwo funkcjonowało od września 1925 roku do września 1939. Na jego łamach informowano o działalności Związku Ukrainek, choć gazeta nie była oficjalnym organem tej organizacji. $Z$ czasem zmieniono profil wydania i coraz więcej artykułów zaczęto poświęcać sprawom wsi i jej mieszkankom. W latach 1932-1939 drukowano dwa dodatki: „Жіноча воля” oraz „Світ молоді”, w którym sporo uwagi poświęcono narodowo patriotycznemu wychowaniu młodych Ukrainek ${ }^{22}$.

W okresie 1935-1938 Związek Ukrainek wydawał czasopismo „Жінка”. Pierwsze wydanie dwutygodnika zredagowano po kongresie kobiet w Stanisławowie w 1934 roku. Gazetę uznano za oficjalny organ lwowskiego oddziału Związku Ukrainek. Redaktorkami zostały Ołena Fedak-Szeparowycz i Milena Rudnicka. Główne cele opublikowano w artykule Przemyślenia nad czasopismem, w którym wskazano m.in. na konieczność łączenia idei feminizmu i nacjonalizmu ${ }^{23}$.

5 kwietnia 1938 roku władze polskie zamknęły Związek Ukrainek. Konsekwencją tej decyzji było również wstrzymanie publikacji „Жінки”. Działania polskiej administracji spotkały się z gwałtownymi protestami ukraińskiej społeczności Lwowa i całej Galicji Wschodniej. Dzięki temu już w październiku organizacja mogła wznowić działalność. Czołowe działaczki ruchu kobiecego zrozumiały jednak, że nieuniknione jest upolitycznienie organizacji, która dotąd starała zachować swą autonomię i niezależność. 12 lipca 1938 roku powstała partia Drużyna Księżnej Olgi [Дружина княгині Ольги], a w jej działalność zaangażowały się mi.in. Milena Rudnicka, Konstantyna Małycka, Ołena Fedak-Szeparowycz oraz Sofija Parfanowycz. Od 1 kwietnia 1939 roku wydawany był dwutygodnik „Громадянка”, który de facto był kontynuacją zamkniętej wcześniej „Жінки”24 .

W październiku 1938 roku powstał „Світ українки”. Jego redaktorką została Ołena Fedak Szeparowycz. Pierwsze wydanie opisywało założenie Drużyny Księżnej Olgi. Gazeta posiadała rubryki poświęcone działalności Związku Ukrainek, wydarzeniom światowym, ochronie zdrowia oraz poradom z dziedziny gospodarstwa domowego. Miesięcznik został zamknięty wraz z wybuchem II wojny światowejej.

W 1931 roku przy Ukraińskiej Partii Radykalno-Socjalistycznej założono organizację Kobieca gromada [Жіноча громада]. Jej przewodniczącą została Iwanna Błaszkewycz, działaczka społeczna i pisarka. Początkowo, w latach 1931-1936 redagowała strony tematyczne poświęcone kobietom w partyjnej gazecie „Громадський голос". Od 1936 wydawała już oddzielny tytuł w całości poświęcony kobietom „Жіночий голос". Za jego pośrednictwem organizacja propagowała idee socjalizmu i zajmowała krytyczne stanowisko wobec oddziału lwowskiego Związku Ukrainek. Podobnie jak w przypadku innych gazet, również to wydawnictwo zawierało w sobie oprócz artykułów z historii międzynarodowego i ruchu kobiecego, a także stałe rubryki związane z twórczością literacką kobiet, pielęgnacją zdrowia i urody oraz prowadzeniem gospodarstwa domowego ${ }^{26}$.

Prasa kobieca wydawana w Galicji Wschodniej w latach 1884-1939 stanowi dobrą bazę źródłową do badań nad rozwojem ruchu kobiecego w tej części Europy. Na jej łamach odzwierciedliły się wszystkie idee i problemy, z którymi nie tylko ten ruch, ale cała ukraińska społeczność stykała się na przełomie wieków.

\footnotetext{
${ }^{22}$ Н. Олійник, Зазнач. праия.

${ }^{23}$ С. Кость, Зазнач. праия.

${ }^{24}$ Tamże.

${ }^{25}$ Tamże.

${ }^{26}$ Tamże.
} 